\title{
Effect of LED light on the inactivation of Bacillus cereus for extending shelf-life of extruded rice cake and simulation of the patterns of LED irradiation by various arrays of LEDs
}

\author{
Hwabin Jung ${ }^{1}$ Hyun-Gyun Yuk ${ }^{2}$ Won Byong Yoon ${ }^{1,3}$ (D)

\section{압출떡의 유통기한 연장을 위한 LED 조사의 Bacillus cereus 억제 효과 및 LED의 배열에 따른 빛의 조사 패턴 시뮬레이션}

\author{
정화빈 ${ }^{1} \cdot$ 육현균 ${ }^{2} \cdot$ 윤원병 1,3
}

Received: 21 March 2019 / Accepted: 14 May 2019 / Published Online: 30 June 2019

(C) The Korean Society for Applied Biological Chemistry 2019

\begin{abstract}
The optimum design of LED device for irradiation of $460 \mathrm{~nm}$ blue light on extruded rice cake using simulation and the effect of the blue light on the inactivation of Bacillus cereus (B. cereus) group on the rice cake were investigated. The irradiated light intensity patterns on the surface area of the sample were simulated with three different LED arrays (centered, cross, and evenly spaced) and at various distances $(22,32,42 \mathrm{~mm})$ between the LED modules and the sample. In addition, the uniformity was calculated as Petri factor. The evenly spaced array resulted the most uniform light intensity pattern in the simulation, and the Petri factor of 32 and $42 \mathrm{~mm}$ of the distances showed higher than 0.9 , which represents the ideal uniformity of LED device. The bacterial population of the rice cake decreased to less than the initial bacterial population during exposure to LED blue light, whereas
\end{abstract}

Won Byong Yoon $(\bowtie)$

E-mail: wbyoon@kangwon.ac.kr

${ }^{1}$ Department of Food Science and Biotechnology, Kangwon National University, Republic of Korea

${ }^{2}$ Department of Food Science and Technology, Korea National University of Transportation, Chungbuk, Republic of Korea

${ }^{3}$ Elderly-Friendly Food Research Center, Agriculture and Life Science and Research Institute, Kangwon National University, Republic of Korea

This is an Open Access article distributed under the terms of the Creative Commons Attribution Non-Commercial License (http://creativecommons. org/licenses/by-nc/3.0/) which permits unrestricted non-commercial use, distribution, and reproduction in any medium, provided the original work is properly cited. the bacterial population of the control sample increased. The bacterial count of the rice cake after blue light irradiation for 24 $\mathrm{h}$ was $1.21 \log \mathrm{CFU} / \mathrm{g}$ lower than the control sample. Petri factor increased with increase of the distance between the light source and sample, however, the reduction rate of $B$. cereus group decreased. Therefore, the design of LED device, that represented the Petri factor higher than 0.9 and inactivated the population of $B$. cereus group, with evenly spaced and $32 \mathrm{~mm}$ of distance between the light source and sample was suitable for extending shelf-life of rice cake.

Keywords Blue light LED $\cdot$ Extending shelf-life $\cdot$ Extruded rice cake $\cdot$ LED irradiation · Optic simulation

\section{서 론}

떡은 한국의 대표적인 전통 식품으로, 그 중 압출떡은 떡볶이 떡 및 떡국떡으로 높은 소비량을 나타내고 있다[1]. 압출떡의 제조공정에서 압출 및 증자 직후에는 고온의 열처리로 인하여 초기 균이 검출되지 않으나, 세척과 건조 공정 및 유통 과정에 서 오염이 발생할 확률이 매우 높다. 또한 전분으로 구성되어 있고 높은 수분을 함유하고 있는 떡의 특성 상 저장 및 유통 과정 중의 온도와 습도 등의 주위 환경 변화에 따라 미생물 안 전성의 유지가 매우 어려워, 대부분 냉장 및 냉동으로 유통이 이루어지고 짧은 유통기한을 가지고 있다.

떡의 짧은 유통기한을 극복하기 위하여 떡 제조 시 자몽 추 
출물과 산도 조절제 첨가[2], 유기산 첨가[3], 천연항균제의 첨 가[4] 등의 방법을 적용하여 유통기한을 연장시키는 연구를 수 행한 바 있다. 그러나 떡의 경우 증자 후에는 균이 검출이 되 지 않으나 균이 공중에서 낙하하거나 공정 중 오염원에 의하여 표면 오염이 될 확률이 높음을 분석한 연구 결과가 있다[5]. 이 를 방지하기 위하여 산업 현장에서는 떡 표면의 균을 제거하고 보관 시 균의 성장 억제를 목적으로 주정을 도포하나 억제 효 과가 낮고 주정으로 인한 이취가 발생하여 소비자 기호도에 영 향을 준다.

최근 식품 표면에서의 병원성 미생물을 방지하고 초기 균의 생육을 억제하여 식품의 유통기한을 연장시키는 방법으로 식품 의 품질에 영향을 미치지 않는 비가열가공기술인 LED (light emitting diode) 조사방법이 주목을 받고 있다[6]. LED는 p-타 입과 $\mathrm{n}$-타입의 반도체의 접합으로 빠르게 빛을 방출시키는 고 효율의 광원으로, 작동 수명이 반영구적이고 크기가 작으며 방 출하는 파장의 범위를 선택할 수 있는 장점이 있다[7]. 기존에 는 살균, 폐수처리, 탈취 등을 위하여 $100-400 \mathrm{~nm}$ 사이의 UV $\mathrm{LED}$ 가 주로 이용되었으나 이는 효과가 뛰어난 반면 인체에 유 해한 단점이 있다[8]. 따라서 최근에는 식품 미생물을 억제하기 위한 새로운 기술로써 균의 광역학적 저해(photodynamic inactivation)가 가능한 가시광선에 대한 연구가 이루어지고 있다. 청색광은 식품 위해균의 내인성 광과민성 물질(endogenous photosensitizer)에 작용하여 균을 억제시키는 데 효과적인 것으 로 알려져 있다[9]. 여러 연구에서 파장 $405-460 \mathrm{~nm}$ 의 청색 가 시광선이 식품 위해균의 감소 및 성장 억제에 효과가 있음을 밝혔으나[10-12], 아직 떡에서 그 효과를 입증한 연구는 이루어 진 바 없다.

주로 UV LED 장치의 이용 시 빛의 조사 패턴과 세기를 균 일하게 하는 디자인을 결정하기 위한 연구가 수행되어 왔으나 [13-15], 식품에 청색광을 조사할 때 빛의 패턴과 균일도를 연 구한 결과는 매우 적다. 이러한 LED 장치에서 $\mathrm{LED}$ 모듈의 배 열에 따른 조사 효과를 확인하기 위하여 광학 모델링 또는 시 뮬레이션이 유용하게 이용될 수 있다[16,17]. 따라서 본 연구에 서는 LED 장치가 식품 표면에 균일하게 청색광을 조사할 수 있는 LED 배열을 시뮬레이션을 통하여 결정하고, 이를 대표적 인 압출 떡인 떡볶이 떡의 표면에 적용하여 청색광이 떡볶이 떡 표면의 식품 위해균 억제에 미치는 영향을 확인하고자 한다.

\section{재료 및 방법}

\section{실험재료}

본 실험에 사용된 떡볶이 떡의 제조를 위하여 미분(Nongshim Flour Mills Co., Asan, Korea)과 소금(CJ Cheiljedang, Seoul, Korea)을 시중에서 구입하여 이용하였다. 재료는 $4{ }^{\circ} \mathrm{C}$ 의 온도에 서 보관하며 이용하였다.

\section{LED 광원 및 조사 장치}

압출떡에 청색광을 조사하기 위하여 파장 $460 \mathrm{~nm}$, 크기 $3 \times 3 \mathrm{~mm}$ 의 LED 광원 LD-CQAR (Osram, München, Germany)을 이 용하였다. LED 조사 장치는 식품의 저장, 유통 및 진열을 목 적으로 설계하였으며, 이에 따라 인체에 미치는 영향이 적으면

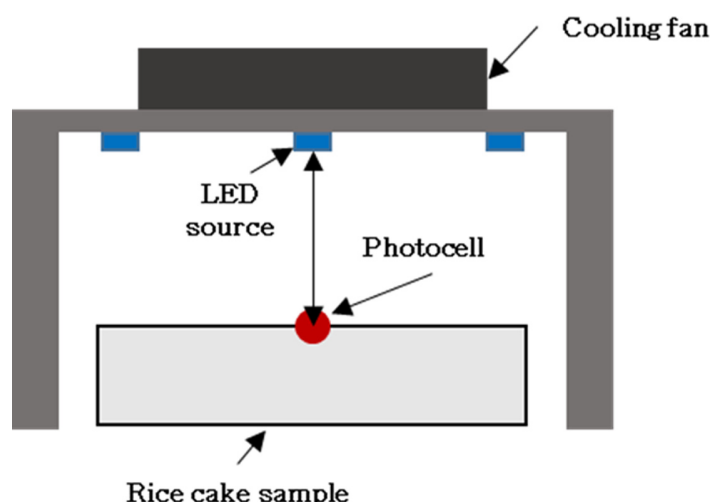

Fig. 1 The LED illumination device for the rice cake

서 균의 억제에 효과가 있는 것으로 알려져 있는 $460 \mathrm{~nm}$ 파장 의 광원을 선택하였다. LED 장치는 9 개의 LED 광원을 보드에 부착하고 교류전원공급장치(KPS305DF, Shenzhen Wanptek Electronic Technology Co., LTD, Shenzhen, China)를 이용하 여 $1.5 \mathrm{~A}$ 의 지속적인 전류를 공급하였고 $\mathrm{LED}$ 에 의한 온도 상 승을 방지하기 위하여 냉각팬을 설치하였다(Fig. 1). LED 장치 의 광원 표면과 떡 표면 사이의 거리에 따른 빛의 세기는 light dependent resistor photocell (Luna Optoelectronics, Camarillo, $\mathrm{CA}, \mathrm{USA}$ )를 이용하여 떡의 중심에서 lux 단위로 측정하였다.

\section{LED 배열 및 광학 시뮬레이션}

LED 장치에 부착된 9개의 LED 모듈의 배열(array) 및 광원과 샘플의 거리에 따라 달라지는 빛의 조사 세기와 패턴을 시뮬레 이션하였다. LED 모듈의 배열을 Fig. 2와 같이 세 가지로 설 정하여 비교하였으며, LED 배열에 따른 빛의 조사 패턴은 Zemax OpticStudio 16.5 (Zemax LLC, Kirkland, WA, USA) 소프트웨어를 이용하여 시뮬레이션 하였다. 시뮬레이션은 nonsequential 모드로 수행하였으며, 광원에 대한 정보는 광원의 제 조사인 Osram사에서 제공하는 파일을 이용하였다. 광선 추적 (ray tracing) 기능을 이용하여 LED로부터 나오는 광선이 detector의 면적에서 나타내는 빛의 세기 패턴을 분석하였으며, 광선 추적 기능은 Monte-Carlo ray-tracing을 기반으로 detector 의 특정 면적에 광선이 도달하는 정도를 확률적으로 계산하여 수행하였다[18]. 시뮬레이션의 빛의 세기는 Osram 사에서 제공 하는 radiant flux 및 power의 측정치를 기준으로 계산하였으며, 광원으로부터 입사되는 빛의 기본적인 굴절에 대한 특성은 Snell's law에 의하여 다음과 같이 계산하였다(Eq. (1)).

$$
n_{1} \sin \theta_{1}=n_{2} \sin \theta_{2}
$$

위의 식에서 $n_{1}$ 과 $n_{2}$ 는 서로 다른 두 매질의 굴절률, $\theta_{1}$ 과 $\theta_{2}$ 는 입사광 및 굴절광의 각도이다.

Detector는 떡 샘플과 동일한 높이의 면적으로 설정하고 250 개의 픽셀에서 얻어진 빛의 세기 데이터를 이용하여 균일도 (uniformity)를 계산하였다. 균일도의 척도로 Petri factor를 계산 하였으며, Eq. (2)과 같이 조사 면적에서 평균 빛의 세기를 중 심의 빛 조사 세기의 비율로 나누어서 나타내었다[13]. 


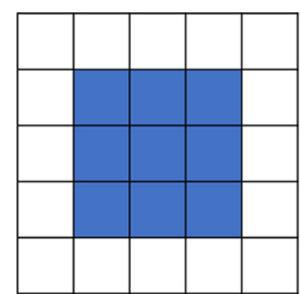

(A) Centered

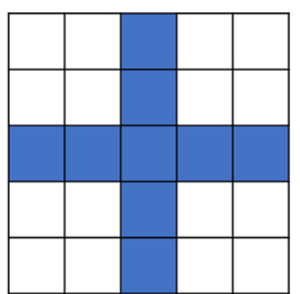

(B) Cross

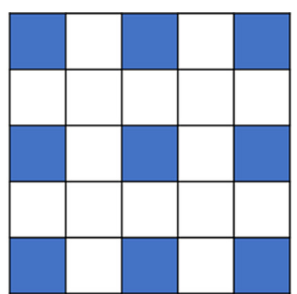

(C) Evenly spaced

Fig. 2 The various arrays of LED device

Petri factor $=\frac{\Sigma\left(I / I_{0}\right)}{n}$

위의 식에서 $I$ 는 특정 위치에서의 빛의 세기, $I_{0}$ 는 면적 중심에 서의 빛의 세기를 의미한다.

\section{Bacillus cereus group의 분리}

떡볶이 떡에서의 LED 청색광의 효과를 열저항성이 높은 떡의 대표적인 식품 위해균인 Bacillus cereus (B. cereus) group을 기준으로 확인하기 위하여, 떡볶이 떡을 제조한 후 $2 \mathrm{~h}$ 동안 $25{ }^{\circ} \mathrm{C}$ 에서 냉각한 후 떡으로부터 균을 분리하였다. B. cereus group의 분리는 식품 공전(고시 제2011-20호) 및 Kim 등[19]의 방법으로 수행하였다. 떡을 희석하여 분쇄한 현탁액을 MYP (mannitol egg yolk polymyxin) agar (Difco, Detroit, Michigan, USA) 배지에 도말하여 배양한 후 colony 중 혼탁한 분홍색 환 을 형성하는 colony를 선별하였다. 이후 멸균된 루프로 colony 를 분리하여 TSA (tryptic soy agar) (Difco) 배지에 평판 획선 하여 접종하고 $37^{\circ} \mathrm{C}$ 에서 $24 \mathrm{~h}$ 동안 배양하였다. 선별된 colony 는 TSB (tryptic soy broth) (Difco) 액체배지에서 $10^{8} \mathrm{CFU} /$ $\mathrm{mL}$ 가 되도록 $37^{\circ} \mathrm{C}$ 에서 $24 \mathrm{~h}$ 동안 배양하여 실험에 이용하였다.

\section{떡볶이 떡 제조 및 샘플 준비}

떡볶이 떡의 제조를 위하여 떡 반죽시 소금의 함량을 미분 대 비 $1 \%$ 가 되도록 첨가하고 미분과 정제수의 비율을 $2: 1$ 로 혼합 하였다. 이후 이를 증자하고 압출하여 떡볶이 떡을 제조하였다. 압출한 떡볶이 떡은 떡 3 개를 가로 $45 \mathrm{~mm}$, 세로 $50 \mathrm{~mm}$, 높이 $15 \mathrm{~mm}$ 가 되도록 배열하여 폴리에틸렌 포장지 내에 포장한 후 $90{ }^{\circ} \mathrm{C}$ 에서 $40 \mathrm{~min}$ 동안 열처리를 통하여 살균하였다. 살균을 완 료한 떡은 떡볶이 떡의 보관 및 유통을 가정하여 냉장 온도인 $4{ }^{\circ} \mathrm{C}$ 로 냉각하였다. 냉각한 떡 샘플의 $\mathrm{LED}$ 를 조사할 표면에 $B$. cereus group 현탁액을 떡 샘플의 초기 균 수가 $10^{6} \mathrm{CFU} / \mathrm{g}$ 이 되도록 접종하고 $30 \mathrm{~min}$ 동안 건조시켰다. 이후 떡의 건조를 방 지하고 포장 상태를 가정하기 위하여 빛이 투과하는 PVC 포장 지로 포장하여 LED 조사 실험에 이용하였다.

\section{LED 조사에 따른 미생물 분석}

$\mathrm{LED}$ 장치가 떡 표면에서 B. cereus group의 균 수에 미치는 영 향을 확인하기 위하여 $2,4,8,12,16,24 \mathrm{~h}$ 동안 빛을 조사하 였으며, LED 장치에 의하여 떡볶이 떡 표면 온도가 $2 \mathrm{~h}$ 후 $4{ }^{\circ} \mathrm{C}$ 에서 $9^{\circ} \mathrm{C}$ 까지 증가하고 $24 \mathrm{~h}$ 까지 $9^{\circ} \mathrm{C}$ 로 유지되는 것을 확인하 였다. 따라서 대조군은 온도 상승 효과를 제외한 LED 빛의 효 과를 비교하기 위하여 $9{ }^{\circ} \mathrm{C}$ 의 인큐베이터 내에서 $\mathrm{LED}$ 조사 실
험군과 동일 시간 동안 보관하며 샘플링을 진행하였다. 또한, $\mathrm{LED}$ 와 떡 표면 사이의 거리에 의한 빛 세기 변화 효과를 확인 하기 위하여 $\mathrm{LED}$ 와 떡 표면 사이의 거리가 $22,32,42 \mathrm{~mm}$ 가 되도록 장치의 높이를 조절하여 세 가지 높이에서 LED 조사에 따른 균 수 변화를 확인하였다. 떡의 균 수는 떡볶이 떡 $10 \mathrm{~g}$ 에 $0.1 \%$ 멸균 펩톤수를 $90 \mathrm{~g}$ 혼합한 후 homogenizer (Polytron PT 2100, Kinematica AG Luzern, Switzerland)를 이용하여 균질화 하였다. 이후 샘플 현탁액을 $0.1 \%$ 펩톤수에 단계적으로 희석하 여 MYP 배지에 평판 도말하였다. 배지는 $30^{\circ} \mathrm{C}$ 에서 $24 \mathrm{~h}$ 동안 인큐베이터에서 배양한 후 colony의 수를 측정하였다.

\section{통계 분석}

본 연구에서 수행된 모든 실험은 3회 이상 반복측정을 하였으 며, 데이터는 SPSS (SPSS Statistics 21, IBM, Armonk, NY, USA) 소프트웨어를 이용하여 분산분석(ANOVA)으로 유의성을 분석하였다 $(p<0.05)$.

\section{결과 및 고찰}

\section{LED의 배열 및 광원의 거리에 따른 빛의 조사 패턴}

광학 시뮬레이션을 통하여 $\mathrm{LED}$ 의 배열 및 $\mathrm{LED}$ 광원과 샘플 의 거리에 따른 조사 패턴을 계산하였다. $\mathrm{LED}$ 의 각 배열을 시 뮬레이션으로 설정한 결과, 9 개의 LED 광원이 가운데에 배치 되어 있는 경우(centered)와 십자형으로 배치되어 있는 경우 (cross) detector의 중심 부위로 광선이 집중되는 것을 확인하였 으며(Fig. 3A), 광원이 장치에 고르게 분포가 되어 있는 경우 (evenly spaced) detector의 가장 바깥 부분까지 비교적 균일하 게 빛이 조사가 되는 것을 확인할 수 있었다(Fig. 3C).

시뮬레이션을 통하여 계산된 다양한 $\mathrm{LED}$ 의 배열(centered, cross, evenly spaced) 및 광원과의 거리 $(22,32,42 \mathrm{~mm})$ 에 따 른 빛의 조사 패턴은 배열 및 거리에 따라 다른 결과를 나타내 었다(Fig. 4). 광원이 장치의 중심에 위치할 경우(centered) 최대 빛의 세기가 세 가지 배열 중 가장 높은 값을 나타내었으나 detector의 면적 내에서 빛의 세기의 편차가 가장 높았다. 반면 균일하게 배열된(evenly spaced) LED의 시뮬레이션 결과 최대 빛의 세기는 세 가지 배열 중 가장 낮았으나, 샘플 면적 내 편 차는 가장 낮은 값을 나타내었다. 광원과의 거리가 멀어짐에 따 라서는 세 가지 배열 모두 빛의 세기가 감소하는 경향을 나타 내었으며, 광원에서 샘플이 멀어질수록 빛의 세기 분포 패턴이 균일하게 변화함을 확인할 수 있었다. 


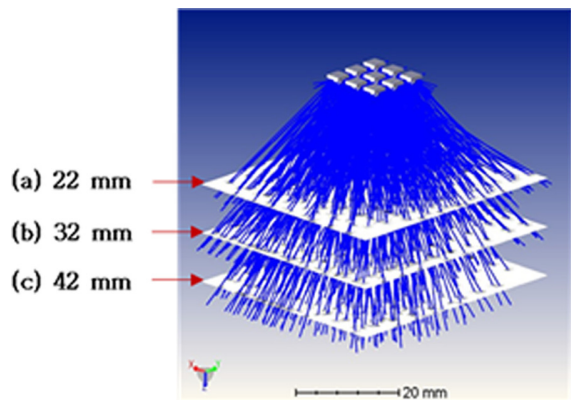

(A) Centered

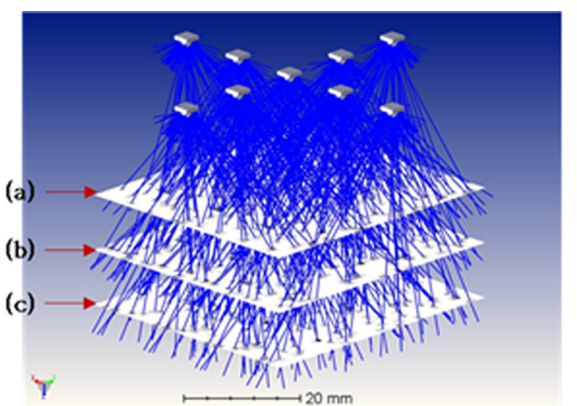

(B) Cross

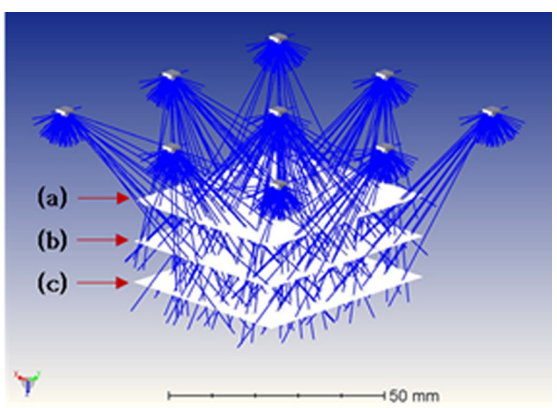

(C) Evenly spaced

Fig. 3 Optical ray tracing simulation of the various arrays of LED modules
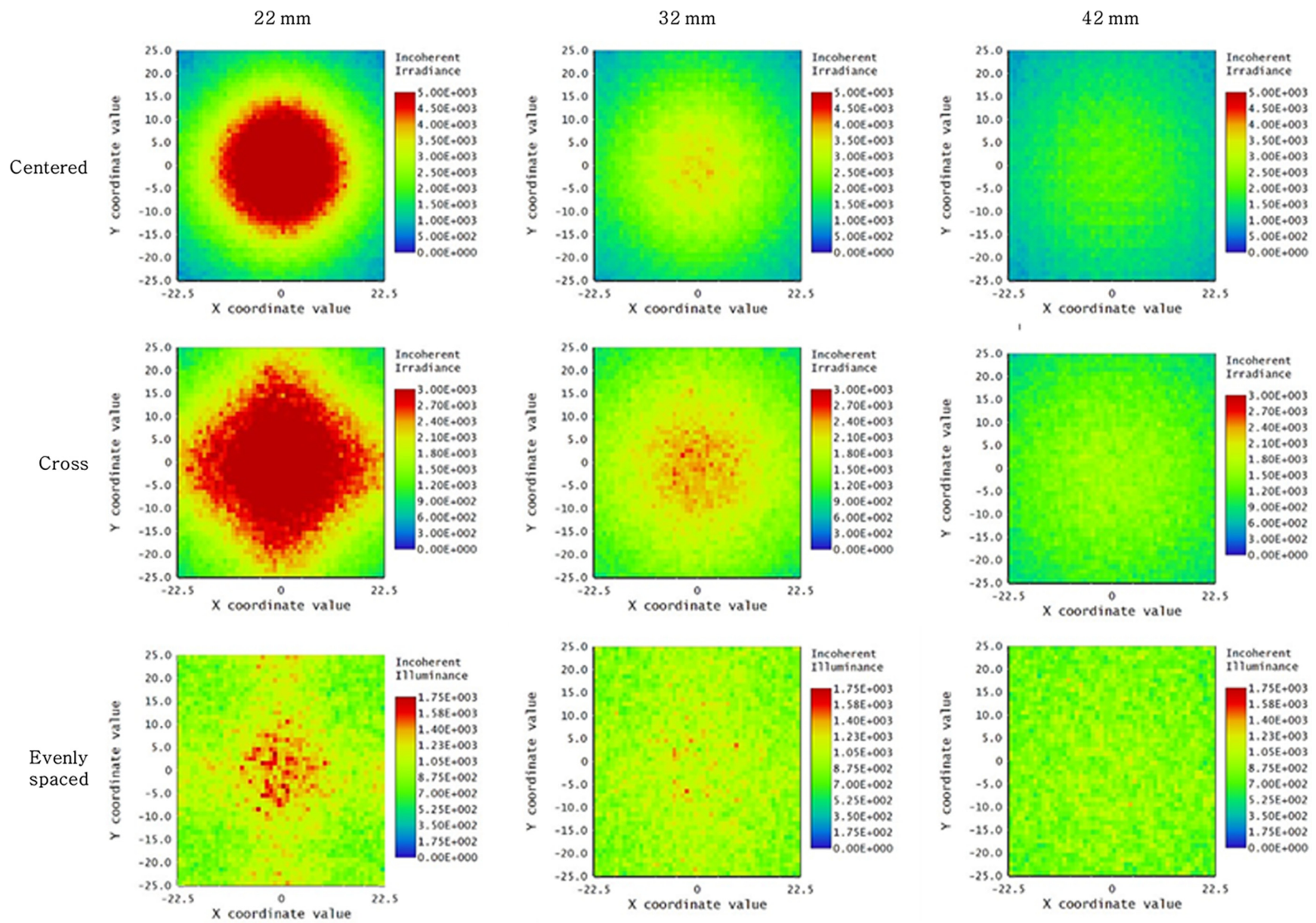

Fig. 4 Simulated irradiation patterns of the various LED arrays

\section{LED의 배열 및 광원의 거리에 따른 Petri factor}

다양한 $\mathrm{LED}$ 의 배열 및 광원과 샘플 사이의 거리에서 detector 면적의 균일도를 예측하기 위하여 시뮬레이션을 통하여 얻은 빛 의 세기로 Petri factor를 계산하였다. 각 조건에서의 Petri factor 는 Table 1 과 같이 계산되었으며, evenly spaced, cross, centered 배열 순으로 Petri factor가 높았다. 또한, 광원으로부터 거리가 멀어질수록 Petri factor가 증가하는 경향을 나타내었다. Petri factor는 1 에 가까울수록 균일도가 높음을 나타내며, 빛을 조사
하는 장치에서 Petri factor가 0.9보다 높아야 균일하게 조사가 되는 이상적인 디자인으로 판단한다[13,15]. 광원의 배열이 centered 및 cross일 경우 Petri factor는 모두 0.9보다 낮았으며, evenly spaced 배열의 경우 광원과의 거리가 $32 \mathrm{~mm}$ 및 42 $\mathrm{mm}$ 일 때 각각 0.91 과 0.93 으로 0.9 보다 높은 균일한 디자인임 을 나타내었다. 본 연구의 결과와 유사하게 UV 범위의 LED 장치에서 빛의 세기가 표면에 고르게 도달하게 하기 위한 연구 가 이루어진 바 있다. 물의 살균 시 UV 장치를 이용하기 위하 
Table 1 Petri factors according to the various LED arrays and distances

\begin{tabular}{cccc}
\hline \hline \multirow{2}{*}{ Array } & \multicolumn{3}{c}{ Height $(\mathrm{mm})$} \\
\cline { 2 - 4 } & 22 & 32 & 42 \\
\hline Centered & 0.44 & 0.61 & 0.72 \\
Cross & 0.65 & 0.72 & 0.79 \\
Evenly spaced & 0.73 & 0.91 & 0.93 \\
\hline
\end{tabular}

여 균일하게 빛을 조사하는 장치를 디자인하기 위하여 Bowker 등[14]은 시뮬레이션을 통하여 계산한 Petri factor로 LED 광원 의 배열 및 샘플과의 거리를 최적화하였다. 또한, Shin 등[15] 은 UV 장치를 이용하여 Escherichia coli O157:H7, Salmonella enterica serovar Typhimurium, Listeria monocytogenes가 고체 의 표면 및 액체 내에 있을 때 감균 효과를 확인하기 위하여 균일하게 빛을 조사하는 UV 모듈의 배열을 Petri factor로 최적 화하였다. 본 연구를 통하여 가시광선을 이용한 식품 저장 장치 에서도 $\mathrm{UV}$ 와 유사하게 각 코너 및 $\mathrm{LED}$ 광원 사이의 거리를 일 정하게 하였을 때 높은 Petri factor를 나타냄을 확인하였다.

\section{가시광선 청색광의 조사 시간에 따른 균 수 변화}

LED 장치의 광원 배열을 evenly distributed로 설계하여 청색광 을 떡볶이 떡에 조사하였을 때 표면의 B. cereus group의 균 수 변화를 확인하였으며, 이를 Fig. 5 에 나타내었다. 초기 균 수 대비 조사 시간에 따른 균의 감소 수를 감소율(reduction rate) 로 확인한 결과, $2 \mathrm{~h}$ 조사 후부터 초기 균 수의 $5 \%$ 가 감소하 고 $16 \mathrm{~h}$ 조사 후 최대 $10.22 \%$ 의 균이 감소하는 것을 확인하였 다. 반면 대조군에서는 $16 \mathrm{~h}$ 저장 후부터 균 수가 $7.32 \%$ 이상 증가하였으며, 이를 통하여 24시간 까지의 LED 조사 시 LED 가 균의 성장을 억제하고 나아가 감균시키는 역할을 하는 것을 확인하였다. 이와 유사하게 Ghate 등[20]의 연구에서는 $461 \mathrm{~nm}$ 파장의 청색 가시광선을 이용하여 trypticase soy broth에서 $\mathrm{pH}$ 가 7.3일 때 Escherichia coli를 $1.2 \pm 0.08 \log \mathrm{CFU} / \mathrm{mL}$ 감균하 였으며, $460 \mathrm{~nm}$ 의 청색광을 냉장 온도의 파인애플에 조사하였 을 때 Salmonella spp.가 0.64-1.00 CFU/g 감균되는 결과를 나 타냈다[21]. 또한 냉장 온도의 오렌지 주스에서 $460 \mathrm{~nm}$ 의 청색 광이 Salmonella spp.를 2.1-3.3 log CFU/g 감균시키는 효과를 연구하였다[22]. 청색광은 미생물의 내인성 광과민성 물질 (endogenous photosensitizer)에 흡수되어 세포가 활성산소종 (reactive oxygen species, ROS)을 생성하도록 하며, ROS는 세 포 독성 반응으로 세포 구성 성분을 손상시켜 파괴시키는 역할 을 한다[23-25]. 떡볶이 떡의 B. cereus group은 열저항성이 높 고 포자를 생성하기 때문에 제어하기 어려운 균으로 알려져 있 으나, 본 연구에서는 $24 \mathrm{~h}$ 의 저장 시간 동안 대조군(control) 대 비 약 $1.21 \log \mathrm{CFU} / \mathrm{g}$ 낮은 균 수를 유지하여 저장 및 유통 시간에 따른 균 수의 증가를 억제하는 것을 확인할 수 있었다.

가시광선 청색광의 조사 거리에 따른 균 수 변화. $\mathrm{LED}$ 와 떡볶 이 떡의 표면 사이의 거리를 $22,32,42 \mathrm{~mm}$ 로 변화시켰을 때 중심에서의 빛의 세기는 각각 $289,254,220 \mathrm{lux}$ 임을 확인하였 다. 광원과 물체 사이의 거리가 증가할수록 빛의 세기는 감소 하며, 이는 Newton의 역제곱 법칙(inverse square law)에 따라 조도가 거리의 제곱에 반비례하여 감소하기 때문이다[26]. 떡볶

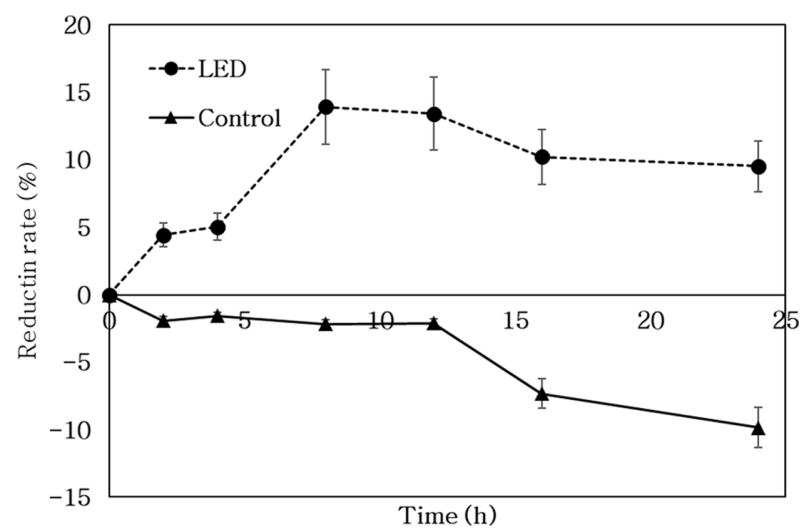

Fig. 5 Reduction rate of $B$. Cereus group during LED irradiation of 460 nm blue light

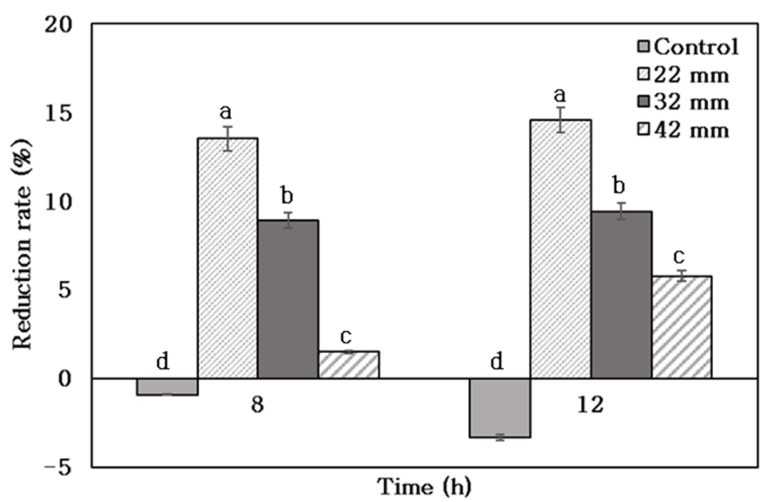

Fig. 6 Reduction rate of $B$. cereus group at different distance between LED modules and the sample surface under LED irradiation

이 떡에서는 광원과 떡 샘플 사이의 거리가 감소할수록 빛의 세기가 증가함에 따라 B. cereus group 균 수의 감소 속도가 유의적으로 증가한 반면(Fig. 6), Petri factor는 광원과 샘플 사 이의 거리가 줄어들수록 감소하였다(Table 1). 유사한 결과로 UV-LED를 이용하여 식품 위해균을 억제한 Shin 등[15]의 연구 에서도 $\mathrm{LED}$ 의 Evenly spaced 배열에서 광원과 샘플의 거리를 $2,4,6,8 \mathrm{~cm}$ 로 조절하였을 때 광원으로부터 거리가 감소할수 록 빛의 세기는 증가하나 Petri factor는 0.5 미만으로 감소하여 불균일한 빛의 조사가 됨을 확인하였다. 따라서 본 연구에서의 $\mathrm{LED}$ 장치를 떡볶이 떡에 조사할 때 떡의 표면에 균일하게 빛 을 조사하면서 미생물의 성장 억제 및 균을 감소시켜 유통기한 을 연장시키기 위한 조건은 evenly spaced 배열의 $32 \mathrm{~mm}$ 거리 조건이 적합함을 확인하였다.

본 연구의 결과를 통하여 식품의 냉장 유통 시 청색 가시광 선 장치가 유통기한의 연장에 이용됨을 확인할 수 있었다. 또한 균일하게 식품의 표면에 빛을 조사하는 최적의 LED 배열을 광 학 시뮬레이션을 통하여 예측 및 설계할 수 있음을 확인하였다.

\section{초 록}

본 연구에서는 $460 \mathrm{~nm}$ 파장의 청색 가시광선을 압출 떡의 표 
면에 조사하기 위하여 장치의 최적 디자인을 시뮬레이션을 통 하여 확인하고 청색광이 압출 떡의 표면에서 식품 위해균인 $B$. cereus group에 미치는 영향을 확인하였다. LED 장치에서 광원 모듈의 세 가지 배열(centered, cross, evenly spaced) 및 광원 과 샘플 표면 사이의 거리 $(22,32,42 \mathrm{~mm})$ 에 따른 조사 면적에 서 빛의 세기 패턴을 시뮬레이션을 통하여 계산하고, Petri factor를 통하여 균일도를 확인하였다. LED 배열의 균일도는 evenly spaced 배열에서 가장 균일한 패턴을 보였으며, 광원과 의 거리가 32 및 $42 \mathrm{~mm}$ 일 경우 Petri factor가 0.9 이상으로 높은 균일도를 나타내었다. 떡볶이 떡에 $\mathrm{LED}$ 청색광을 조사한 경우 $24 \mathrm{~h}$ 후 균 수가 초기 균 수에 비하여 감소하였으며, LED 를 조사하지 않은 대조군에서는 초기 균 수가 증가하여 1.21 $\log \mathrm{CFU} / \mathrm{g}$ 의 차이를 보였다. LED 조사 시 광원과 샘플의 거 리가 증가할수록 Petri factor는 증가하나 감균 효과가 낮아지는 결과를 나타내었다. 따라서 Petri factor가 0.9 이상임을 만족하 는 evenly spaced 배열의 $32 \mathrm{~mm}$ 거리가 떡의 유통기한 연장을 위한 LED 장치의 디자인에 적합함을 확인하였다.

Keywords LED 조사· LED 청색광 - 광학 시뮬레이션 · 압출떡 · 유통기한 연장

감사의 글 본 결과물은 농림축산식품부의 재원으로 농림식품기술기획평가 원의 농축산물 안전생산 - 유통관리기술개발사업의 지원을 받아 연구되었음 (318079-02)

\section{References}

1. Jung H, Yu CR, Park HW, Yoon WB (2018) Effect of acid soaking and thermal sterilization on the shape and quality characteristics of Tteokbokki rice cake. Korean J Food Nutr 31(5): 737-750

2. Kang HJ, Lee JK, Lim JK (2012) Quality characteristics of Toppokki Garaedduk with different moisture ratios. J Korean Soc Food Sci Nutr 41(4): 561-565

3. Cheon HS, Cho WI, Lee SJ, Chung MS, Choi JB (2017) Acidic and steaming treatments of tteokbokki rice cake to improve its microbial and textural properties. Korean J Food Sci Technol 49(5): 502-506

4. Yoo SJ, Chin JE, Oh SH, Ryu MJ, Hwang K (2018) A study on the evaluation of distribution stability of refrigerated rice cake using natural antibiotics. J Chitin Chitosan 23(4): 244-255

5. Lee HS, Jang MS (2008) The development of the HACCP plan in Korean rice cake manufacturing facilities. Korean J Food Cookery Sci 24(5): 652-664

6. Do JS, Chung HJ, Bang WS (2015) Bactericidal effect of pathogenic bacteria on acid treatment combined with red, green, and blue LED light at a low temperature environment. J Korean Soc Food Sci Nutr 44(11): $1725-1732$

7. Shen S, Huang H, Chao C, Huang M (2013) Design and analysis of a high-intensity LED lighting module for underwater illumination. Appl Ocean Res 39: 89-96

8. Maclean M, MacGregor SJ, Anderson JG, Woolsey G (2009) Inactivation of bacterial pathogens following exposure to light from a 405-nanometer light-emitting diode array. Appl Environ Microbiol 75(7): 1932-1937

9. D'Souza C, Yuk HG, Khoo GH, Zhou W (2015) Application of lightemitting diodes in food production, postharvest preservation, and microbiological food safety. Compr Rev Food Sci Food Saf 14(6): 719740

10. Kim MJ, Bang WS, Yuk HG (2017) $405 \pm 5 \mathrm{~nm}$ light emitting diode illumination causes photodynamic inactivation of Salmonella spp. on fresh-cut papaya without deterioration. Food Microbiol 62: 124-132

11. Miranda FS, Silva JJB, Amor ALM, Silva IMM (2018) Using light emitting diodes at $450 \mathrm{~nm}$ for in vitro treatment of water intended for human consumption. Afr J Microbiol Res 12(29): 681-687

12. Josewin SW, Ghate V, Kim MJ, Yuk HG (2018). Antibacterial effect of $460 \mathrm{~nm}$ light-emitting diode in combination with riboflavin against Listeria monocytogenes on smoked salmon. Food Control 84: 354-361

13. Bolton JR, Linden KG (2003) Standardization of methods for fluence (UV dose) determination in bench-scale UV experiments. J Environ Eng 129(3): 209-215

14. Bowker C, Sain A, Shatalov M, Ducoste J (2011) Microbial UV fluenceresponse assessment using a novel UV-LED collimated beam system. Water Res 45(5): 2011-2019

15. Shin JY, Kim SJ, Kim DK, Kang DH (2016) Fundamental characteristics of deep-UV light-emitting diodes and their application to control foodborne pathogens. Appl Environ Microbiol 82(1): 2-10

16. Moreno I, Sun CC (2008) Modeling the radiation pattern of LEDs. Opt Express 16(3): 1808-1819

17. Simons R, Gabbai U, Moram M (2014) Optical fluence modelling for ultraviolet light emitting diode-based water treatment systems. Water Res 66: $338-349$

18. Consonni M, Routin J, Piveteau A, Gasse A (2013) Combined experimental and Monte-Carlo ray-tracing approach for optimizing light extraction in LED COB modules. ISRN Optics 2013: 385-345

19. Kim JY, Yoo HL, Lee YD, Park JH (2011) Detection of Bacillus cereus group from raw rice and characteristics of biofilm formation. Korean J Food \& Nutr 24(4): 657-663

20. Ghate V, Leong AL, Kumar A, Bang WS, Zhou W, Yuk HG (2015) Enhancing the antibacterial effect of 461 and $521 \mathrm{~nm}$ light emitting diodes on selected foodborne pathogens in trypticase soy broth by acidic and alkaline $\mathrm{pH}$ conditions. Food Microbiol 48: 49-57

21. Ghate V, Kumar A, Kim MJ, Bang WS, Zhou W, Yuk HG (2017) Effect of $460 \mathrm{~nm}$ light emitting diode illumination on survival of Salmonella spp. on fresh-cut pineapples at different irradiances and temperatures. J Food Eng 196: 130-138

22. Ghate V, Kumar A, Zhou W, Yuk HG (2016) Irradiance and temperature influence the bactericidal effect of 460-nanometer light-emitting diodes on Salmonella in orange juice. J Food Prot 79(4): 553-560

23. Hamblin MR, Hasan $T$ (2004) Photodynamic therapy: a new antimicrobial approach to infectious disease?. Photochem Photobiol Sci 3(5): 436-450

24. Luksiene Z, Buchovec I, Paskeviciute E (2009) Inactivation of food pathogen Bacillus cereus by photosensitization in vitro and on the surface of packaging material. J Appl Microbiol 107(6): 2037-2046

25. Kumar A, Ghate V, Kim MJ, Zhou W, Khoo GH, Yuk HG (2017) Inactivation and changes in metabolic profile of selected foodborne bacteria by $460 \mathrm{~nm}$ LED illumination. Food Microbiol 63: 12-21

26. Kim MS, Sohn KR (2015) Performance investigation of visible light communication using super bright white LED and Fresnel lens. J Korean Soc of Marine Engineering 39(1): 63-67 